\title{
FORMULASI ANTISEPTIK TANGAN EKSTRAK DAUN SIRIH (Piper betle L.) DENGAN BAHAN PENSTABIL TEA (Trietanolamin)
}

Formulation Of Hand Antiseptic Gel from Betel Leaf (Piper Betle L.) Extract with the Addition of Triethanolamine (TEA) Stabilizer

\author{
Samantha, Yusya' Abubakar, Yuliani Aisyah \\ Program Studi Teknologi Hasil Pertanian, Fakultas Pertanian, Universitas Syiah Kuala \\ Darussalam, Banda Aceh, Indonesia \\ *Email: sasasha62@gmail.com
}

\begin{abstract}
Antiseptics are chemical compounds that are usually used to inhibit or kill the growth of microorganisms. Betel plant is one of the plants that contain active substances that can have an antibacterial effect. The analysis carried out in this study includes the analysis of physical, chemical and microbiological properties. The best antiseptic gel formulation was found in $25 \%$ betel leaf extract and $0.75 \%$ TEA (K1P2). The test results on the $\mathrm{pH}$ properties of the antiseptic gel showed that the $\mathrm{pH}$ of the antiseptic gel produced was in accordance with SNI No. 4075-2:2017. The highest antiseptic gel viscosity value was obtained from the interaction of $35 \%$ betel leaf extract concentration and 1\% TEA concentration, which was $2551.07 \mathrm{cP}$. All antiseptic gel formulations showed a homogeneous composition and there were no coarse grains. The results of the description test assessment on the best treatment K1P2 showed a very strong yellow color scale, a very weak scale of betel leaf aroma, a neutral scale gel texture and a neutral scale non-sticky texture. Betel leaf extract antiseptic gel has antibacterial activity against $\mathrm{S}$. aureus and $\mathrm{E}$. coli bacteria.
\end{abstract}

Keywords: Antiseptic gel, betel leaf, Triethanolamine (TEA)

\begin{abstract}
ABSTRAK
Antiseptik adalah suatu senyawa kimia yang biasanya digunakan untuk menghambat maupun membunuh pertumbuhan mikroorganisme. Tanaman sirih merupakan salah satu tanaman yang mempunyai kandungan zat aktif yang dapat memberi efek antibakterial. Analisis yang dilakukan dalam penelitian ini meliputi analisis fisik, kimia dan sifat mikrobiologis. Formulasi gel antiseptik terbaik terdapat pada ekstrak daun sirih $25 \%$ dan TEA $0,75 \%$ (K1P2). Hasil pengujian terhadap sifat $\mathrm{pH}$ gel antiseptik menunjukkan bahwa $\mathrm{pH}$ gel antiseptik yang dihasilkan sesuai dengan SNI No. 4075-2:2017. Nilai viskositas gel antiseptik tertinggi diperoleh dari interaksi konsentrasi ekstrak daun sirih 35\% dan konsentrasi TEA 1\% yaitu 2551,07 cP. Seluruh formulasi gel antiseptik menunjukkan susunan yang homogen dan tidak terdapat butiran-butiran kasar. Hasil penilaian uji deskripsi pada perlakuan terbaik K1P2 menunjukkan warna kuning skala sangat kuat, aroma daun sirih skala sangat lemah, tekstur gel skala netral dan tekstur tidak lengket skala netral. Gel antiseptik ekstrak daun sirih memiliki aktivitas antibakteri terhadap bakteri $S$. aureus dan bakteri E. coli.
\end{abstract}

Kata Kunci: Gel antiseptik, daun sirih, TEA (Trietanolamin)

\section{PENDAHULUAN}

Antiseptik adalah suatu senyawa kimia yang biasanya digunakan untuk menghambat maupun membunuh pertumbuhan mikroorganisme dalam jaringan hidup dan mempunyai efek mencegah ataupun membatasi adanya infeksi agar tidak menjadi lebih parah. Dipasaran banyak ditemukan antiseptik yang berbahan alkohol dengan konsentrasi hingga $70 \%$ yang dapat menyebabkan kulit kering serta iritasi jika dipakai secara berulang.

Saat ini banyak orang yang ingin menggunakan antiseptik yang berbasis alam atau back to nature. Salah satu antiseptik yang mengandung antibakteri yaitu dari daun sirih. Daun sirih mengandung minyak atsiri seperti hidroksikavikol, estargiol, kavibetol, eugenol, metileugenol, terpen, karvakrol, fenilpropan, dan fenol. Senyawa yang berfungsi sebagai antiseptik yaitu fenol dan fenilpropan (Muhlisan, 2007). 
Sirih merupakan jenis tumbuhan merambat yang biasanya tumbuh bersandar pada batang pohon yang lain. Tanaman sirih memiliki tinggi 5-15 meter, batang tanaman sirih berbentuk bulat, memiliki ruas dan tempat keluar akar serta warnanya coklat kehijauan. Daun sirih merupakan daun tunggal dengan bentuk seperti jantung, ujungnya runcing, tepi rata, tulang daun melengkung, daunnya memiliki lebar 2,5-10 cm, panjang daun yaitu $5-18 \mathrm{~cm}$, memiliki tangkai, tumbuhnya 8 berselang-seling serta bau sedap yang dikeluarkan jika daun diremas (Ayu et al., 2019).

Bahan-bahan lain yang digunakan dalam pembuatan gel antiseptik tangan adalah gliserin yang berfungsi sebagai humektan, dan memberikan efek lembut pada kulit. Gliserin memiliki sifat yang juga mengikat lembab sehingga mampu mengurangi penguapan air dari formulasi sediaan yang dapat meningkatkan ketahanan suatu gel. Selain gliserin, juga digunakan karbopol 940 sebagai gelling agent dan dapat meningkatkan viskositas sediaan gel. Karbopol 940 mampu membentuk matrik tiga dimensi yang merupakan salah satu faktor yang penting dalam sistem gel, memiliki efisiensi dengan viskositas yang ting gi dalam membentuk gel dan menghasilkan sediaan gel yang bening.

Sari \& Isadiartuti (2006), yang menguji daya antiseptik dari suatu sediaan gel yang mengandung berbagai konsentrasi ekstrak daun sirih $(5 \%, 10 \%, 15 \%, 20 \%$ dan 25\%), melaporkan bahwa sediaan gel ekstrak daun sirih memiliki daya antiseptik, terutama pada ekstrak daun sirih dengan konsentrasi $25 \%$ mampu menghilangkan seluruh mikroorganisme yang ada di telapak tangan.

Daun sirih yang memiliki konsentrasi yang semakin tinggi, maka kemampuannya dalam menghambat pertumbuhan bakteri juga akan semakin kuat. Hal ini dikarenakan daun sirih mengandung jumlah zat antibakteri yang disetiap peningkatan konsentrasi akan semakin bertambah (Kusuma et al., 2017). Hasil penelitian Yendriwati (2008) juga menunjukkan bahwa daun sirih memiliki efek antibakteri terhadap beberapa bakteri.

Pada penelitian ini, digunakan ekstrak daun sirih dalam pembuatan gel antiseptik tangan, dan TEA (Trietanolamin). Masalah rendahnya $\mathrm{pH}$ yang diakibatkan oleh konsentrasi ekstrak daun sirih yang semakin tinggi dapat diatasi dengan menggunakan TEA. Karena TEA merupakan agen pengalkali yang dapat mengatur tingkat keasaman sediaan gel yang dihasilkan sehingga aman bagi pengguna. Dalam penelitian ini, TEA juga dapat berfungsi sebagai penetral pH karbopol karena jika karbopol dicampurkan dengan air maka akan membentuk larutan asam yang keruh. Konsentrasi TEA akan divariasikan agar diperoleh sediaan gel yang memiliki kemampuan antibakteri, serta $\mathrm{pH}$ dan viskositas yang sesuai dengan persyaratan untuk gel antiseptik tangan.

Penelitian ini dilakukan untuk mengetahui formulasi yang tepat dalam pembuatan gel antiseptik tangan dengan menggunakan ekstrak daun sirih yang memiliki kemampuan sebagai antibakteri dan penambahan TEA untuk mendapatkan gel antiseptik yang memiliki sifat kimia, sifat fisik dan aktivitas antiseptik yang tinggi.

Tabel 1. Standar Mutu Detergen Sintetik Pembersih Tangan SNI 4075-2:2017

\begin{tabular}{clc}
\hline No. & Jenis Uji & Persyaratan \\
\hline 1 & Kadar zat aktif & Min. 10\% \\
2 & pH & $4-10$ \\
3 & Emulsi cairan & Stabil \\
\hline
\end{tabular}




\begin{tabular}{|c|c|c|}
\hline 4 & Zat tambahan & $\begin{array}{l}\text { Sesuai peraturan yang } \\
\text { berlaku }\end{array}$ \\
\hline 5 & Bahan yang tidak larut dalam etanol & Maks. 0,5\% \\
\hline 6 & Alkali bebas (dihitung sebagai $\mathrm{NaOH}$ ) & Maks. $0,05 \%$ \\
\hline 7 & $\begin{array}{l}\text { Asam lemak bebas (dihitung sebagai } \\
\text { asam oleat) }\end{array}$ & Maks. $1 \%$ \\
\hline
\end{tabular}

\section{METODE PENELITIAN}

Penelitian ini dilakukan di Laboratorium Analisis Pangan dan Hasil Pertanian, Laboratorium Mikrobiologi Pangan dan Industri dan Laboratorium Uji Sensori Jurusan Teknologi Hasil Pertanian Fakultas Pertanian Universitas Syiah Kuala.

\section{MATERI DAN METODE}

\section{Bahan Dan Alat}

Alat-alat yang digunakan pada penelitian antiseptik ekstrak daun sirih ini adalah vacuum rotary evaporator, timbangan analitik, $\mathrm{pH}$ meter, viskometer, blender, pisau stainless, talenan, sendok pengaduk, baskom, erlenmeyer, termometer, aluminium foil, timbangan, cawan petri, beaker glass, pipet tetes, botol jar, gelas ukur, corong, plastik wrap dan kertas saring. Bahanbahan yang digunakan pada penelitian ini adalah daun sirih hijau (Piper betle L.), TEA (Trietanolamin), Karbopol 940, gliserin, natrium metabisulfit, aquadest, etanol 96\%, Bakteri Escherichia coli dan Staphylococcus aureus.

\section{Prosedur Penelitian}

\section{Pembuatan Ekstrak Daun Sirih}

Daun sirih 1000 gram dicuci bersih lalu dikeringkan selama 3-4 hari dengan cara diangin-anginkan diruangan terbuka dan tidak terkena cahaya matahari langsung untuk menghindari terjadinya kerusakan zat kimia yang terkandung dalam daun sirih. Setelah kering, daun sirih dipotong kecil-kecil dan diblender sampai menjadi serbuk yang halus, serta dianalisis kadar airnya. Pada penelitian ini analisis kadar air yang digunakan adalah dengan menggunakan metode oven. Pada penelitian ini kadar air yang diuji adalah daun sirih kering dan serbuk daun sirih. Untuk hasil kadar air pada daun sirih kering yaitu 1,45\% sedangkan hasil kadar air pada serbuk daun sirih yaitu $0,43 \%$. Serbuk daun sirih dimasukkan kedalam botol kaca dan diberi pelarut etanol 96\% (perbandingan 1:5) dan dimasukkan magnetik stirrer. Kemudian dimaserasi selama 72 jam pada suhu ruangan. Ekstrak daun sirih disaring dengan menggunakan corong dan kertas saring untuk memisahkan antara filtrat dan ampasnya. Lalu, pelarut yang masih terdapat pada ekstrak daun sirih diuapkan untuk mendapatkan ekstrak kental dengan menggunakan vacuum rotary evaporator dengan suhu $40^{\circ} \mathrm{C}$.

\section{Pembuatan Antiseptik Ekstrak Daun Sirih}

Bubuk karbopol 940 diubah menjadi gel dengan cara ditambahkan air panas $70^{\circ} \mathrm{C}$ sebanyak $10 \mathrm{ml}$ lalu diaduk hingga mengembang dan membentuk gel. Dicampurkan ekstrak daun sirih masing-masing 25\%, 30\% dan 35\% dari $200 \mathrm{ml}$ aquadest serta bahan lainnya (Gliserin 1\% dan Natrium Metabisulfit 0,2\% dari $200 \mathrm{ml}$ aquadest) hingga tercampur rata, kemudian dimasukkan kedalam karbopol 940. Ditambahkan aquadest $200 \mathrm{ml}$ kedalam 
campuran tersebut. Ditambahkan tetes demi tetes TEA masing-masing 0,5\%, 0,75\% dan $1 \%$ sambil diaduk perlahan hingga terbentuk gel yang jernih.

\section{Pengamatan dan Analisis Data}

Pengamatan yang akan dilakukan yaitu sifat kimia $(\mathrm{pH})$, sifat fisik (viskositas dan homogenitas) dan sifat organoleptik deskripsi (warna, aroma, tekstur dan kesan lengket), dan sifat mikrobiologis (aktivitas antibakteri). Data pengamatan yang diperoleh dianalisis menggunakan Analysis of Variance (ANOVA) dan uji lanjut menggunakan Duncan Multiple Range Test (Duncan).

\section{HASIL DAN PEMBAHASAN}

\section{Sifat Kimia Gel Antiseptik (pH)}

Menurut Sari (2017), pH kosmetik diusahakan sama atau mendekati dengan $\mathrm{pH}$ fisiologis kulit yaitu 4,5-6,5. Nilai pH gel antiseptik yang dihasilkan pada penelitian ini telah sesuai dengan SNI yaitu berkisar antara 5,29 - 5,99 dengan rataan 5,65. Jika pH suatu sediaan terlalu rendah maka akan menyebabkan iritasi pada kulit, sedangkan jika $\mathrm{pH}$ suatu sediaan terlalu tinggi akan menyebabkan kulit menjadi bersisik (Lukman et al., 2013).

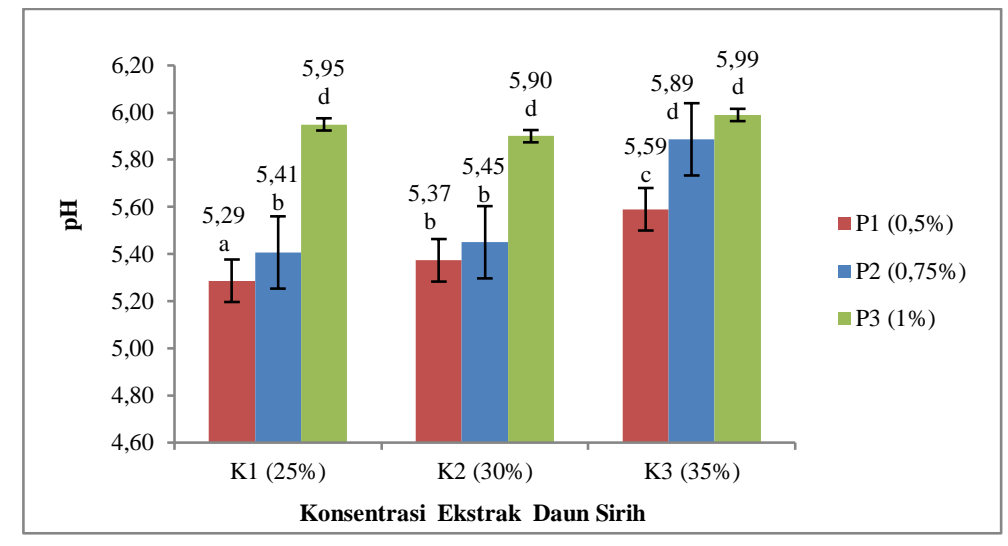

Gambar 1. Pengaruh interaksi konsentrasi ekstrak daun sirih (K) dan konsentrasi TEA (P) terhadap $\mathrm{pH}$ gel antiseptik

Berdasarkan uji DMRT (Gambar 1) dapat dilihat bahwa terjadi peningkatan pH gel antiseptik baik dalam peningkatan jumlah konsentrasi ekstrak daun sirih yang ditambahkan maupun dalam peningkatan jumlah konsentrasi TEA yang ditambahkan. Gambar 1 menunjukkan bahwa peningkatan jumlah konsentrasi TEA yang ditambahkan. perlakuan K3P3 memiliki pH 5,99 yang berbeda tidak nyata dengan perlakuan K1P3 $(5,95)$, K2P3 $(5,90)$, dan K3P2 $(5,89)$.

\section{Sifat Fisik Gel Antiseptik Viskositas}

Viskositas adalah suatu parameter yang dapat menunjukkan bagaimana sifat fisik suatu sediaan gel hand sanitizer ekstrak daun sirih hijau yang mempengaruhi suatu sediaan mudah mengalir atau tidak mudah mengalir (Angnes, 2016). Viskositas gel antiseptik pada penelitian ini berkisar antara 1263,37 - 2551,07 cP dengan rataan 1848,63 cP. 


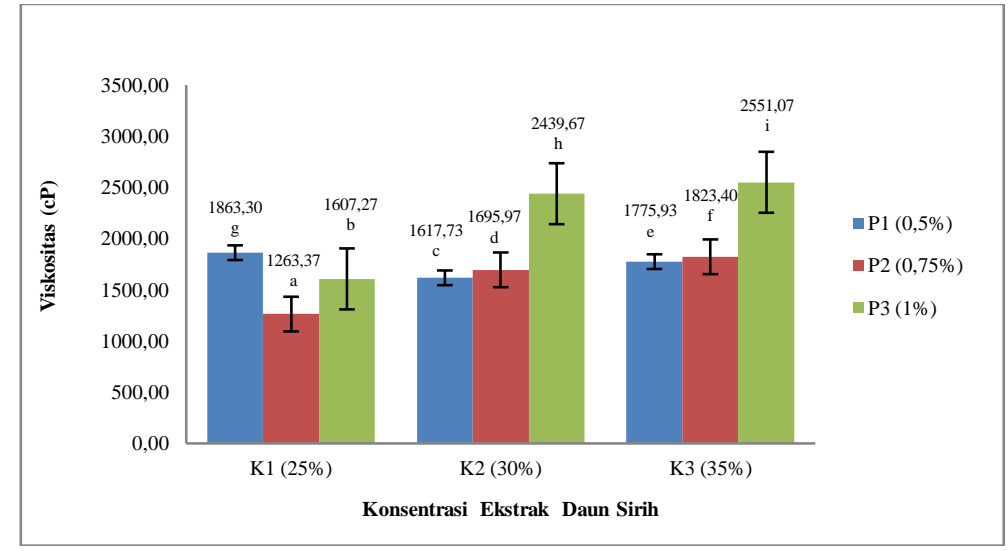

Gambar 2. Pengaruh interaksi konsentrasi ekstrak daun sirih (K) dan konsentrasi TEA $(\mathrm{P})$ terhadap viskositas gel antiseptik

Berdasarkan uji DMRT (Gambar 2) dapat dilihat bahwa viskositas gel antiseptik daun sirih tertinggi diperoleh dari interaksi konsentrasi ekstrak daun sirih 35\% dan konsentrasi TEA $1 \%$ (K3P3; 2551,07 cP) yang berbeda nyata dengan perlakuan lainnya. Hal ini seiring dengan $\mathrm{pH}$, dimana jika $\mathrm{pH}$ suatu gel antiseptik meningkat maka viskositas gel antiseptik juga akan meningkat karena besarnya nilai viskositas dipengaruhi oleh nilai $\mathrm{pH}$. Menurut Nurwaini \& Saputri (2018), peningkatan viskositas disebabkan oleh penambahan konsentrasi ekstrak yang menyebabkan sediaan gel hand sanitizer menjadi lebih kental karena semakin tinggi konsentrasi ekstrak maka kandungan airnya akan lebih sedikit.

\section{Homogenitas}

Uji homogenitas dilakukan untuk mengetahui apakah cara pembuatan dan pencampuran bahan-bahan gel antiseptik daun sirih telah tercampur dengan rata. Dari hasil pengamatan yang dilakukan, sediaan gel antiseptik menunjukkan struktur yang homogen dan tidak terdapat partikel yang tidak larut (gel yang menggumpal).

Dari hasil pengamatan, sediaan gel antiseptik pada setiap formulasi menunjukkan struktur yang homogen dan tidak terdapat partikel yang tidak larut yang dapat mengakibatkan berkurangnya daya homogenitas. Sediaan gel antiseptik yang homogen menunjukkan bahwa bahan-bahan yang digunakan tercampur rata sehingga tidak terdapat gumpalan maupun butiran kasar pada sediaan karena jika sediaan gel antiseptik tidak homogen dan terdapat gumpalan maupun butiran kasar maka dapat mengakibatkan iritasi pada kulit (Rukmana, 2017).

Tabel 2. Hasil Pengamatan Homogenitas Gel Antiseptik

Sampel Homogenitas

\begin{tabular}{ll}
\hline Daun Sirih 25\% ; TEA 0,5\% & Homogen \\
Daun Sirih 25\%; TEA 0,75\% & Homogen \\
Daun Sirih 25\%; TEA 1\% & Homogen \\
Daun Sirih 30\%; TEA 0,5\% & Homogen \\
Daun Sirih 30\%; TEA 0,75\% & Homogen \\
Daun Sirih 30\%; TEA 1\% & Homogen \\
Daun Sirih 35\%; TEA 0,5\% & Homogen \\
Daun Sirih 35\%; TEA 0,75\% & Homogen \\
Daun Sirih 35\%; TEA 1\% & Homogen \\
\hline
\end{tabular}




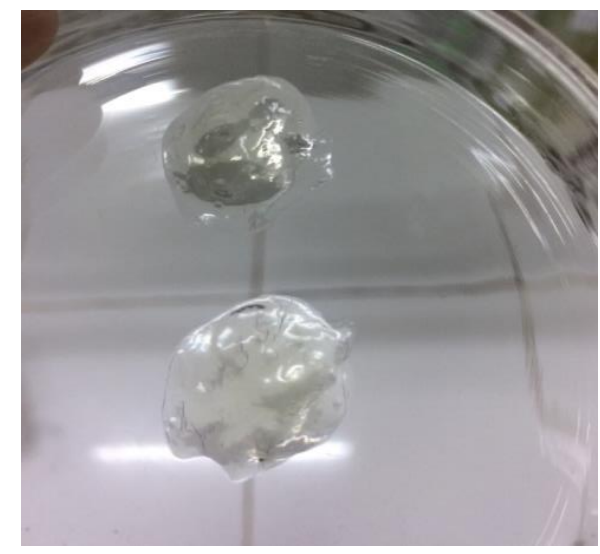

Gambar 3. Gel Antiseptik yang Homogen

\section{Sifat Organoleptik (Uji Deskripsi) Gel Antiseptik}

Uji organoleptik yang dilakukan dalam penelitian ini adalah uji deskripsi. Garis grafik yang menjauhi titik pusat (0) maka nilai deskripsinya semakin lemah dan garis yang berada pada skala angka yang tinggi menunjukkan kuatnya parameter (aroma, warna, tekstur, kesan lengket).

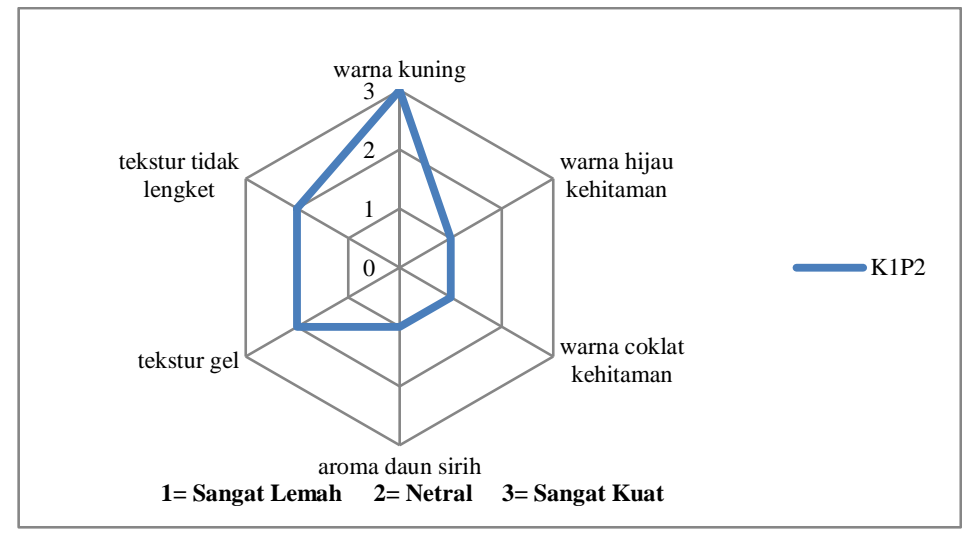

Gambar 4. Grafik majemuk uji deskripsi gel antiseptik dengan konsentrasi ekstrak daun sirih $25 \%$ dan konsentrasi TEA $0,75 \%$ (K1P2)

Hasil penilaian uji deskripsi warna menunjukkan bahwa gel antiseptik pada formulasi konsentrasi ekstrak daun sirih 25\% dan konsentrasi TEA 0,75\% (K1P2) dengan penambahan bahan lain seperti gliserin 1\%, karbopol 940 0,5\% , natrium metabisulfit $0,2 \%$ dan penambahan aquadest $200 \mathrm{ml}$ diperoleh warna kuning dengan skala sangat kuat (skala 3). Menurut Simatupang (2018), semakin tinggi penambahan konsentrasi ekstrak daun sirih, maka warna dari sediaan gel yang dihasilkan akan bertambah pekat, mulai dari coklat muda cerah hingga coklat muda keruh.

Aroma daun sirih memiliki skala yang sangat rendah (skala 1). Aroma daun sirih yang lemah disebabkan karena semakin tinggi penambahan konsentrasi ekstrak daun sirih maka aroma yang dihasilkan juga akan semakin kuat. Seperti pada penelitian yang dilakukan oleh 
Anggreini \& Asngad (2018), bahwa semakin tinggi penambahan konsentrasi ekstrak daun serai, maka aroma yang dihasilkan juga akan semakin kuat.

Pada tesktur gel antiseptik dihasilkan skala yang netral (skala 2). Tekstur gel yang netral disebabkan oleh penggunaan TEA yang mampu menghasilkan gel antiseptik yaitu tidak terlalu cair dan tidak terlalu kental, namun masih dapat digunakan dengan mudah ketika meneteskan dan mengaplikasikan gel antiseptik ke tangan (Mentari, 2015). Tekstur tidak lengket pada antiseptik memiliki skala yang netral (skala 2). Hal ini sama seperti organoleptik tekstur yang memperoleh hasil tekstur gel yang netral karena TEA yang mampu menghasilkan antiseptik dengan viskositas berbeda. Antiseptik yang memiliki tekstur gel sangat kental dengan skala sangat kuat akan membuat kesan lengket.

\section{Sifat Mikrobiologis (Aktivitas Antibakteri)}

Bakteri uji yang digunakan dalam penelitian ini adalah Staphylococcus aureus dan Escherichia coli yang merupakan bakteri penyebab berbagai macam penyakit. Sedangkan kontrol positif digunakan sebagai pembanding untuk mengetahui kemampuan aktivitas antibakteri ekstrak daun sirih yang diformulasikan dalam gel. Kontrol positif yang digunakan adalah Vankomisin untuk bakteri S. aureus dan kloramfenikol untuk bakteri E. coli.

Tabel 3. Rata-rata diameter zona hambat konsentrasi ekstrak daun sirih dan konsentrasi TEA terhadap bakteri S. aureus dan E. coli (mm)

\begin{tabular}{cccc}
\hline \multicolumn{2}{c}{ Perlakuan } & S. aureus & E. coli \\
\cline { 1 - 2 } $\begin{array}{c}\text { Konsentrasi } \\
\text { Ekstrak Daun } \\
\text { Sirih }\end{array}$ & Konsentrasi TEA & & \\
\cline { 1 - 2 } & & & \\
25\% (K1) & $0,5 \%(\mathrm{P} 1)$ & $8,3 \pm 1,13$ & $8,23 \pm 0,59$ \\
& $0,75 \%(\mathrm{P} 2)$ & $9,27 \pm 1,55$ & $8,13 \pm 0,86$ \\
& $1 \%(\mathrm{P} 3)$ & $9,03 \pm 1,05$ & $8,4 \pm 0,46$ \\
& & & \\
\hline & $0,5 \%(\mathrm{P} 1)$ & $9,23 \pm 0,86$ & $8,4 \pm 0,78$ \\
& $0,75 \%(\mathrm{P} 2)$ & $8,73 \pm 0,75$ & $8 \pm 0,3$ \\
& $1 \%(\mathrm{P} 3)$ & $8,83 \pm 0,57$ & $9,23 \pm 0,58$ \\
& & & \\
\hline & $0,5 \%(\mathrm{P} 1)$ & $10,53 \pm 0,35$ & $9,8 \pm 0,69$ \\
$35 \%(\mathrm{~K} 3)$ & $0,75 \%(\mathrm{P} 2)$ & $9,43 \pm 1,22$ & $9,07 \pm 0,51$ \\
& $1 \%(\mathrm{P} 3)$ & $9,57 \pm 0,6$ & $10,2 \pm 0,75$ \\
\hline Kontrol (+) & & $16,7 \pm 1,04$ & $20,5 \pm 1,7$ \\
Kontrol (-) & & $5,83 \pm 0,76$ & $5,4 \pm 0,69$ \\
\hline
\end{tabular}

Berdasarkan Tabel 3, dapat dilihat bahwa gel antiseptik ekstrak daun sirih memiliki aktivitas antibakteri terhadap bakteri S. aureus dan bakteri E. coli. Aktivitas antibakteri gel antiseptik terhadap bakteri $S$. aureus adalah 8,3 - 10,53 $\mathrm{mm}$ dengan rataan 9,21 $\mathrm{mm}$. Sedangkan, aktivitas antibakteri gel antiseptik terhadap bakteri $E$. coli adalah 8,0 - 10,2 mm dengan rataan $8,83 \mathrm{~mm}$. Hasil penelitian ini sesuai dengan beberapa penelitian sebelumnya, seperti Sari \& 
Isadiartuti (2006) yang menyatakan bahwa sediaan gel ekstrak daun sirih memiliki daya antiseptik.

Pada tabel juga dapat dilihat bahwa, penambahan ekstrak daun sirih dan penambahan TEA yang semakin meningkat tidak menghasilkan zona daya hambat yang meningkat pula. Tidak terjadinya peningkatan zona daya hambat pada ekstrak daun sirih yang semakin tinggi diduga karena selama penelitian sebagian media agar yang akan digunakan terkontaminasi dan konsentrasi zak aktif antimikroba yang berbeda pada setiap formulasi. Menurut Salni et al (2011), perbedaan zona hambat yang dihasilkan pada masing-masing perlakuan (formulasi) dapat diakibatkan karena perbedaan besar dan kecilnya konsentrasi zat aktif antimikroba yang terkandung dalam formulasi, kepekaan pertumbuhan bakteri, $\mathrm{pH}$ lingkungan, komponen media dan waktu inkubasi.

Menurut Susanto (2012), diameter zona hambat dikelompokkan menjadi empat kategori, yaitu diameter zona hambat kategori lemah $(\leq 5 \mathrm{~mm})$, diameter zona hambat kategori sedang $(6-10 \mathrm{~mm})$, diameter zona hambat kategori kuat $(11-20 \mathrm{~mm})$ dan diameter zona hambat kategori sangat kuat $(\geq 21 \mathrm{~mm})$. Hasil zona hambat gel antiseptik ekstrak daun sirih pada seluruh perlakuan dikategorikan memiliki zona hambat yang sedang $(6-10 \mathrm{~mm})$.

\section{KESIMPULAN} berikut:

Berdasarkan data hasil penelitian dan pembahasan dapat diambil kesimpulan sebagai

1. Gel antiseptik ekstrak daun sirih menggunakan ekstrak daun sirih 35\% dan TEA 0,5\% memiliki diameter daya hambat tertinggi terhadap bakteri S. aureus yaitu $10,53 \mathrm{~mm}$. Sedangkan gel antiseptik dengan menggunakan ekstrak daun sirih 35\% dan TEA $1 \%$ memiliki daya hambat tertinggi terhadap bakteri $E$. coli yaitu 10,2 mm.

2. Interaksi konsentrasi ekstrak daun sirih dan konsentrasi TEA berpengaruh sangat nyata $(\mathrm{P} \leq 0,01)$ terhadap $\mathrm{pH}$ dan viskositas gel antiseptik.

3. Gel antiseptik ekstrak daun sirih menunjukkan struktur yang homogen dan tidak terdapat partikel yang tidak larut.

4. Hasil penilaian uji deskripsi warna, aroma, tekstur, dan kesan lengket menunjukkan bahwa gel antiseptik K1P2 memiliki karakteristik yang paling baik.

5. Perlakuan terbaik dalam penelitian ini berdasarkan sifat kimia dan sifat fisik gel antiseptik ekstrak daun sirih yaitu gel antiseptik dengan konsentrasi ekstrak daun sirih 25\% dan konsentrasi TEA 0,75\% (K1P2) karena memiliki nilai terbaik pada setiap uji.

\section{SARAN}

Pada penelitian ini perlu dilakukan penelitian lebih lanjut yaitu untuk menambah komposisi atau bahan tambahan lain yang memberikan warna yang lebih menarik, serta melakukan uji efektivitas (uji finger print) untuk mengetahui kadar hambat minimum (minimum inhibitory concentration $=$ MIC) dan kadar bunuh minimum (minimum killing concentration $=$ MKC) terhadap mikroorganisme. 


\section{DAFTAR PUSTAKA}

Anggreini, C. K., \& Asngad, A. (2018). Hand Sanitizer Dalam Bentuk Gel Dari Daun Serai Dengan Penambahan Alkohol Dan Triklo. Seminar Nasional Pendidikan Biologi Dan Saintek Iii, 126-130.

Angnes, Y. (2016). Pengaruh Karbopol 940 dan Gliserin dalam Formulasi Gel Hand Sanitizer Minyak Atsiri Daun Sirih Hijau (Piper betle Linn) Terhadap Sifat Fisik, Stabilitas Fisik dan Aktivitas Antibakteri Terhadap Escherichia coli. 1-96.

Ayu Kartika Putri, Quinne Eannatum Satwika, Yanti Sulistyana, Z. A. (2019). Studi Morfologi Piper betle L. dan Pemanfaatannya dalam Kehidupan Sehari - Hari.

Kusuma, M., Susilorini, T., \& Surjowardojo, P. (2017). Pengaruh Lama Dan Suhu Penyimpanan Ekstrak Daun Sirih Hijau (Piper Betle Linn) Dengan Aquades Terhadap Daya Hambat Bakteri Streptococcus Agalactiae Penyebab Mastitis Pada Sapi Perah. TERNAK TROPIKA Journal of Tropical Animal Production, 18(2), 14-21.

Lukman, A., Susanti, E., dan Oktaviana, R. (2013). Formulasi Sediaan Gel Minyak Kulit Kayu Manis (Cinnamomum burmanii BI) sebagai Sediaan Antinyamuk. Jurnal Penelitian Indonesia, 1(1), 24-29.

Mentari, G. (2015). Pengaruh Karbopol 940 dan Sorbitol dalam Formulasi Gel Hand Sanitizer Minyak Daun Sirih Hijau (Oleum Piper betle L.) dan Uji Aktivitas Antibakteri.

Muhlisan, F. (2007). Tanaman Obat Keluarga (Toga). Journal of Linguistics.

Nurwaini, S., \& Saputri, I. D. (2018). Pengujian Sifat Fisik dan Aktivitas Antibakteri Sediaan Gel Hand Sanitizer Ekstrak Daun Lidah Mertua (Sansevieria trifasciata Prain). Talenta Conference Series: Tropical Medicine (TM), 1(3), 078-085.

Rukmana, W. (2017). Formulasi Dan Uji Stabilitas Fisik Sediaan Salep Antifungi Ekstrak Daun Ketepeng Cina (Cassia Alata L.). Skrip, 87(1,2), 149-200.

Salni, S., Marisa, H., \& Mukti, R. (2011). Isolasi Senyawa Antibakteri Dari Daun Jengkol (Pithecolobium lobatum Benth) dan Penentuan Nilai KHM-nya. Jurnal Penelitian Sains, 14(1), 168193.

Sari, R. G. (2017). Formulasi dan Uji Aktivitas Antibakteri dari Sediaan Gel Hand Sanitizer Ekstrak Daun Belimbing Wuluh (Averrhoa bilimbi L .) Terhadap Bakteri Escherichia Coli dan Staphylococcus Aureus. USU.

Sari, R., \& Isadiartuti, D. (2006). Studi Efektivitas Sediaan Gel Antiseptik Tangan Ekstrak Daun Sirih (Piper betle Linn.). Majalah Farmasi Indonesia, 17(4), 163-169.

Simatupang, E. J. (2018). Formulasi Sediaan Gel Hand Sanitizer Dari Ekstrak Etanol Daun Jambu Air (Syzygium aqueum (Burm. F.) Alston).

Susanto, D., S. dan R. R. (2012). Studi Kandungan Bahan Aktif Tumbuhan Meranti Merah (Shorea leprosula Miq) sebagai Sumber Senyawa Antibakteri. Mulawarmnan Scientifie, 11 (2), 181-190. 